\title{
TERAPI MURATTAL SURAT AR-RAHMAN MENURUNKAN STRES KEHAMILAN
}

\author{
Anni Annisa, Program Studi DIII Kebidanan Universitas Wiraraja \\ E-mail: annianisa@wiraraja.ac.id \\ Emdat Suprayitno, program Studi profesi Ners Universitas Wiraraja \\ E-mail: emdats@yahoo.com
}

\begin{abstract}
Pregnancy is a life process that women will experience after marriage. But not all women have the chance to get pregnant, it is very natural for many women who consider pregnancy to be an extraordinary period so that women focus on filling their pregnancy with activities that make the fetus grow healthy. Spikologis reactions such as stress in pregnant women caused a non-smooth process and the risks experienced by pregnant women, so not all women have a smooth pregnancy.

This type of research uses quasy-experiment using one group pre-post test design test. Therapy is measured by the stress level of pregnant women for 15 minutes after Qs therapy. The beneficent. Murattal Audio Qs. Ar-Rahman and the DASS (Depression Anxiety Stress Scales) questionnaire.

In this study, researchers used the sample technique in an incidental manner. The sample used as many as 56 pregnant women, consisting of 28 pregnant women who work as career women and 28 people who work as housewives

After the Murattal therapy of Qs Ar-Rahman in 56 respondents there was a decrease in the stress level of pregnant women. 35 respondents of pregnant women experienced mild stress with a percentage of $62.5 \%$, with moderate stress as many as 15 pregnant women with a percentage of $26.8 \%$. While for severe stress 6 pregnant women with a percentage of $10.7 \%$.
\end{abstract}

\section{Keyword: Ar-Rahman Therapy, Stress In Pregnancy}

\section{PENDAHULUAN}

Kehamilan merupakan proses kehidupan yang akan dialami wanita setelah menikah. Namun tidak semua wanita mempunyai kesempatan hamil, sangat wajar jika banyak wanita yang menganggap masa kehamilan adalah masa yang luar biasa sehingga wanita fokus mengisi masa hamil dengan kegiatan yang membuat janin tumbuh sehat. Reaksi spikologis seperti stres pada ibu hamil ditimbulkan adanya proses yang tidak lancar dan resiko yang dialami ibu hamil, sehingga tidak semua wanita memiliki kehamilan yang lancar.

Stres adalah gangguan pada tubuh dan pikiran yang disebabkan oleh perubahan dan tuntunan kehidupan, yang dipengaruhi baik oleh lingkungan maupun penampilan individu di dalam lingkungan tersebut. Faktor makro dan faktor mikro adalah dua faktor yang menyebabkan timbulnya stress. Stress yang disebabkan peristiwa dahsyat dalam kehidupan, contoh kematian orang yang dicintai, perceraian, luka batin dan kegagalan dalam berbisnis, semua ini merupakan salah satu faktor makro. Sedangkan stres yang disebabkan peristiwa kecil yang terjadi dalam kehidupan sehari-hari, seperti pertikaian kecil antara suami dan istri, dan beban pekerjaan merupakan bagian dari faktor mikro. Pada masa kehamilan, stres disebabkan oleh sejumlah kehidupan yang dialaminya seperti kurangnya ilmu tentang kehamilan, kurangnya dukungan dari lingkungan sekitar dan kondisi ekonomi yang murat-marit serta proses penyesuaian diri terhadap kehamilan baik secara fisik bentuk tubuh yang berubah drastis maupun secara spikososial. (Gross, Helen, 2007)

Stress berlebihan menimbulkan dampak signifikan pada wanita hamil dan janin. Resiko kelahiran prematur dan peningkatan rasa sakit melahirkan baik secara normal maupun caesar, serta rendahnya berat badan bayi merupakan dampak dari stres berlebihan pada ibu hamil. Yali dan Lobel menyatakan bahwa stres penyebab utama kelahiran prematur dan kematian bayi di Amerika Serikat. (Yali \& Lobel, 2002) Penenelitian ini berlangsung selama dua dekade terakhir dan membuktikan bahwa prediksi bagaimana proses kelahiran 
berlangsung dipengaruhi oleh stres pada periode akhir kehamilan. Begitu juga kelahiran premature sangat dipengaruhi adanya stres pada trimester kedua.

Setiap individu memiliki cara tersendiri untuk mengatasi stress. Salah satunya terapi murottal surat Ar-Rahman. Hal ini diperkuat oleh Dr. Al Qadhi direktur utama Islamic Medicine Institute for Education and research di Florida, Amerika Serikat, beliau melakukan penelitian tentang pengaruh signifikan yang terdapat dalam mendengarkan tilawah AlQur'an pada manusia sehingga merasakan perubahan fisiologis dan spikologis yang sangat besar. Diyakini adanya 97\% terapi murattal Al-Qur'an menurunkan ketegangan urat saraf reflektik dan hasil ini tercatat dan terukur secara kuantitatif dan kualitif oleh alat berbasis kompurer. (Remolda, 2009)

Murattal Al-Qur'an yang paling sering digunakan adalah surat Ar-Rahman. Qs. ArRahman merupakan surat yang diturunkan di Madinah, terdiri dari 78 surat. Rasulullah memberi nama lain Surah Ar-Rahman dengan julukan Al- 'Arus Al-Qur'an yang memiliki arti pengantin Al-Qur'an. Hal ini diperkuat dengan keindahan satu ayat "Maka nikmat Tuhanmu yang manakah yang kamu dustakan”. Satu ayat pemecah rekor pengulangan yang ada dalam Al-Qur'an sebanyak 31 kali pengulangan. Pengulangan ini bertujuan untuk mengingatkan manusia tentang nikmat luar biasa yang Allah berikan pada manusia. Saat seseorang meningkatkan rasa syukur, disitulah ketenanganhati semakin meningkat.

\section{METODE PENELITIAN}

Jenis penelitian ini menggunakan quasyeksperimen menggunakan one grup test prepost test design yaitu suatu kegiatan yang dilakukan sebelum diberikan pelakuan terhadap suatu variable dan diharapkan dengan perlakuan perlakuan tersebut akan terjadi perubahan atau pengaruh dengan variable lain. (Notoatmodjo, 2012, hlm. 162).

Peneletian bertujuan untuk mengetahui seberapa besar tingkatan stres sebelum dan sesudah pemberian terapi murattal surat ArRahman. Setelah mengetahui tingkatan stres ibu hamil sebelum terapi barulah dilakukan terapi dan diukur kembali tingkat stres ibu hamil selama 15 menit setelah terapi Qs. Ar-
Rahman. Audio murattal Qs. Ar-Rahman dan kuesioner DASS (Depression Anxiety Stress Scales) adalah dua instrument pengumpulan data yang digunakan untuk mengukur tingkat stres.

Dalam penenelitian ini, peneliti menggunakan teknik sampel dengan cara incidental. Sampel yang digunakan sebanyak 56 orang wanita hamil, yang terdiri dari 28 wanita hamil yang berprofesi sebagai wanita karier dan 28 orang yang berprofesi sebagai ibu rumah tangga. Penelitian Ini dilakukan pada bulan Maret sampai Mei 2019.

HASIL PENELITIAN

\begin{tabular}{cc}
\hline Data & Jumlah \\
\hline Trimeter & \\
\hline Trimeter pertama & 15 \\
Trimeter kedua & 16 \\
Trimeter ketiga & 25 \\
\hline Umur & \\
\hline 17-25 tahun & 16 \\
26-35 tahun & 30 \\
$>36$ tahun & 10 \\
\hline Urutan Kehamilan & \\
\hline kehamilan pertama & 20 \\
Kehamilan kedua & 36 \\
\hline
\end{tabular}

Berdasarkan tabel di atas, terdapat 56 responden penelitian. Ada 15 responden yang usia kehamilan di trisemester pertama (fase pembuahan sampai minggu ke dua belas), dan di usia kehamilan trisemester kedua ( fase minggu ke tiga belas hingga ke dua pulu delapan) berjumlah 16 responden.

Mayoritas responden penelelitian berada pada rentang usia 26-36 dengan jumlah 30 responden, sedang 16 responden dengan usia rentang 17-25, dan rentang usia 36 ke atas sebanyak 10 responden.

Ada 20 responden yeng mengalami kehamilan pertama dan 36 responden yang mengalami kehamilan kedua.

Tabel 2. Distribusi frekuensi tingkat stress responden sebelum dilakukan terapi murattal Qs. Ar-Rahman

\begin{tabular}{ccc}
\hline Tingkat Stres & F & $\%$ \\
\hline Sedang & 25 & 44,6 \\
Berat & 31 & 55,4 \\
\hline
\end{tabular}

Tabel 2 di atas membuktikan adanya 25 responden ibu hamil mengalami stres sedang dengan persentase $44,6 \%$. Dan terdapat 31 
responden dengan persentase $55,4 \%$ mengalami stress berat

Tabel 3. Distribusi frekuensi tingkat stress responden setelah dilakukan terapi murattal Qs. Ar-Rahman

\begin{tabular}{ccc}
\hline Tingkat Stres & F & $\%$ \\
\hline Ringan & 35 & 62,5 \\
Sedang & 15 & 26,8 \\
Berat & 6 & 10,7 \\
\hline
\end{tabular}

Berdasarkan tabel 3 di atas, tingkat stres pada ibu hamil semakin menurun sesudah dilaksanakan terapi Qs Ar-Rahman. Yang mengalami stres ringan berjumlah 35 responden $(62,5 \%)$, stres sedang berjumlah 15 responden $(26,8 \%)$. Sedangkan ibu hamil yang mengalami stres berat sebanyak 6 orang $(10,7 \%)$.

\section{PEMBAHASAN}

Dari hasil penilitian menunjukkan bahwa tingkat stress 25 responden ibu hamil sebelum dilakukan terapi murattal Qs. ArRahman mengalami stres sedang dengan persentase $44,6 \%$, sedangkan stres berat 31 responden dengan persentase 55,4\%. Maka dapat dikatakan bahwa sebagian besar wanita hamil mengalami stres berat. Tanda stres berat yang dijumpai pada wanita hamil adalah mengalami badmood berkepanjangan, sedih berlebihan, insomnia atau gangguan tidur, perasaan bersalah dan tidak berharga, kosentrasi yang buruk, mengalami pusing berlebihan, mengalami gangguan pencernaan yang tidak kunjung sembuh. Salah satu faktor penyebab tingginya tingkat stress yang dialami oleh ibu hamil adalah perubahan fisik pada diri ibu hami dipengaruhi adanya perubahan hormonal, minimnya ilmu pengetahuan tentang kehamilan, masalah ekonomi keuangan, kehamilan yang tidak diinginkan, sehingga menimbulkan stres berkepanjangan pada ibu hamil. Stres berat pada ibu hamil memiliki dampak negatif pada ibu hamil dan perkembangan janin dalam kandungan.

Terapi dengan alunan bacaan murattal Qs. Ar-Rahman merupakan alternatif terapi baru sebagai terapi relaksasi bahkan memiliki kwalitas lebih tinggi jika dibandikan dengan terapi audio lainnya, hal ini disebabkan adanya stimulan surat Ar-Rahman dapat memunculkan gelombang delta sebesar 63,11\% (Maryani, 2013).

Setelah dilakukan terapi murattal Qs Ar-Rahman pada 56 responden terdapat penurunan tingkat stres ibu hamil. Sebanyak 35 responden ibu hamil mengalami stres ringan dengan persentase $62,5 \%$, yang stres sedang sebanyak 15 ibu hamil dengan persentase 26,8\%. Sedangkan untuk stres berat 6 ibu hamil dengan persentase 10,7\%.

Ayat al-Qur'an dapat memberikan nutrisi pada otak dengan getaran akustik yang besar sehingga mempengaruhi sel-sel otak dan mengembalikan keseimbangannnya. Selain itu juga berkontribusi dalam koordanasi antara suara, sebab getaran al-Qur'an memilki konsistensi yang menakjubkan. Mendengarkan bacaan al-Qur'an juga meningkatkan sistem kekebalan tubuh terdapat dalam sel-sel. Sebab pengaruh getaran akustik yang sangat seimbang menjadikan sel bekerja dengan sempurna (Al-Kaheel, 2012).

Terapi murattal Al-Qur'an memiliki dampak spikologis ke arah positif bagi ibu hamil, karena murattal Al-Qur'an mampu menembus otak dan hati manusia, sehinggah Al-Qur'an ini akan diinput dan otak dan hati. Sedangkan persepsi seseorang akan ditentukan oleh otak semua yang lebih terakumulasi, keinginan hasrat, kebutuhan, dan penilaian. Zat kimia yang disebut neuropeptide diprodiksi oleh otak manusia yang dirangsang dengan terapi murattal Al-Qur'an. Molekul ini akan masuk ke dalam reseptor-reseptor yang ada dalam tubuh dan memberi umpan balik berupa kenikmatan dan kenyamanan (O'Riordon, 2002). Dengan adanya terapi ini maka meningkatkan kualitas kesadaran seseorang terhadap Tuhan, sehingga menimbulkan totalitas kepasrahan kepada Tuhan. Dalam keadaan ini otak berada pada gelombang frekuensi 7-14 Hz, ini merupakan keadaan energy otak yang optimal dan dapat menyingkirkan stress dan kecemasan (Mac Gregor, 2011).

\section{KESIMPULAN}

Berdasarkan hasil penelitian yang dilakukan tentang terapi murattal Qs. Ar-Rahman menurunkan stres kehamilan dapat disimpulkan sebagai berikut: 
1. Penelitian ini membuktikan adanya 25 responden ibu hamil mengalami stres sedang dengan persentase $44,6 \%$. Dan terdapat 31 responden dengan persentase $55,4 \%$ mengalami stress berat

2. tingkat stres pada ibu hamil semakin menurun sesudah dilaksanakan terapi Qs ArRahman. Yang mengalami stres ringan berjumlah 35 responden $(62,5 \%)$, stres sedang berjumlah 15 responden $(26,8 \%)$. Sedangkan ibu hamil yang mengalami stres berat sebanyak 6 ibu hamil dengan persentase $10,7 \%$.

\section{DAFTAR PUSTAKA}

Al-Kaheel, A.D. (2012). Pengobatan Qur'any manjurnya berobat dengan Al-Qur'an. Jakarta: Amzah

Gross, H. \& Helen, P.(2007). Researching Pregnancy: Psychilogical Perspective. New York: Routledge

Mac Gregor, S. (2011). Piece of Mind: Menggunakan Pikiran Bawah Sadar untuk Mencapai Tujuan. Jakarta: PT Gramedia.

Maryani, E. D., \& Hartati, E. 2013. Intervensi Terapi Audio Dengan Murottal Surah Ar-Rahman Terhadap Perilaku Anak Autis. Jurnal Keperawatan Soedirman.

Notoadmojo, S. (2012). Metodologi Penelitian Kesehatan. Jakarta: Rineka Cipta.

O'Riordon, 2002. Keperawatan Media Bedah. Edisi 2 Volume 1. EGC: Jakarta.

Yali, A.M \& Lobel, M. (2002). Stressresistence Resources and Coping in Pregnancy. Journal of Anxiety, Stress and Coping. Taylor \& Francis Health sciences: USA. 